\title{
The Effect of Diet with Certain Glycemic Index and Exercise with Blood Glucose Levels and Insulin of Type 2 Diabetes Patients In Minangkabau Ethnicity
}

\author{
Masrul $^{1}$, Elly Usman ${ }^{2}$ \\ \{masrulmuchtar@med.unand.ac.id ${ }^{1}$, ellyusman@med.unand.ac.id ${ }^{2}$ \}
}

Department of Nutrition, Faculty of Medicine, Universitas Andalas Padang, Indonesia ${ }^{1}$

Department of Pharmacology, Faculty of Medicine, Universitas Andalas Padang, Indonesia ${ }^{2}$

\begin{abstract}
The aim of this study to determine the effect of a diet with certain glycemic index and exercise with blood glucose levels and insulin of type 2 diabetes mellitus patients in Minangkabau ethnicity. This experimental study design was conducted in Padang City from June to December 2017. The number of samples was 55 respondents aged $>40$ years patient given diet and exercise consultation for 3 months and seen blood glucose and insulin patients with type 2 diabetes mellitus. The subjects of this study are T2DM patients. Nutritional consultation intervention in the form of diet with diet modification based on the glycemic index according to the type of diet for type 2 diabetes mellitus patients to be carried out at home for 1 month. Exercise intervention for 1 month, based on: a) intensity, adjusted for fitness test results or use the formula: $60-90 \%$ (220 - age) to get a maximum pulse. Speed is the travel time compared to distance, $b$ ) the duration is 30-45 minutes, c) the frequency is at least 3 times a week. Bivariate analysis of the data in this study was used to find the mean difference of blood glucose and insulin levels between pretest and posttest using paired sample T-test. Data were analyzed by using STATA program. A twotailed P-value of $<0.05$ was considered statistically significant. Data were analyzed using the Stata version 14.2 (Stata Corporation). The results showed blood glucose levels before intervention were $142.6 \pm 48.5 \mathrm{mg} / \mathrm{dL}$, while after intervention $133.0 \pm 47.0 \mathrm{mg} / \mathrm{dL}$. Statistical test results obtained $p=0.039(p<0.05)$, there is an effect of a diet with certain glycemic index and exercise with blood glucose levels of type 2 diabetes mellitus patients in Minangkabau ethnicity. Insulin levels before intervention were $11.4 \pm 9.9 \mu \mathrm{LU} / \mathrm{ml}$, while after intervention $8.4 \pm 9.1 \mu \mathrm{LU} / \mathrm{ml}$. Statistical test results obtained $\mathrm{p}=0.163$ $(p>0.05)$ there is no effect of a diet with certain glycemic index and exercise with insulin levels of type 2 diabetes mellitus patients in Minangkabau ethnicity. This analysis confirmed there is an effect of a diet with certain glycemic index and exercise with blood glucose levels of type 2 diabetes mellitus patients in Minangkabau ethnicity.
\end{abstract}

Keywords: Body Mass Index, Diet, Exercise, Insulin, Type 2 Diabetes Mellitus.

\section{Introduction}

Diabetes mellitus (DM) is a global health problem because its prevalence tends to increase from years with high morbidity and mortality. It is estimated that the prevalence will increase $55 \%$ of the number of sufferers currently in both developed and developing countries. Prevalence is type 2 diabetes mellitus is $85-95 \%$. The increase in the prevalence of Type 2 
Diabetes Mellitus (T2DM) is caused by the influence of environmental factors, among others lifestyle, unbalanced diet and physical activity, which will cause excess weight [1].

The proportion of DM causes in urban areas was $14.7 \%$ and $5.8 \%$ in rural areas. The high number of morbidity makes Indonesia occupy the rank fourth in the world after China, India and United States of America. Without effective control efforts, the prevalence of DM will increase. DM sufferers have the potential to suffer from various complications including macrovascular and microvascular diseases. Various DM complications cause the patient's life expectancy to decrease 15 years, $75 \%$ of patients die of macrovascular complications [2-4].

Hyperglycemia that occurs in people with diabetes mellitus results in increased production of Reactive Oxygen Species (ROS) in mitochondria so that it can trigger oxidative stress. As a result, the ROS formed can inhibit insulin signal delivery by phosphorylation of serine residues from insulin receptors and insulin substrate receptors (IRS), inactivation of tyrosine phosphatase and JNK pathway inactivation (c Jun-N-terminal kinase) $[5,6]$.

Insulin resistance is a condition in which target organs such as muscles, adipose tissue and liver do not provide an adequate response to the physiological effects of insulin. Insulin resistance plays an important role in the pathogenesis of T2DM and other metabolic syndromes such as hypertension, dyslipidemia and heart disease. In the course of the disease, insulin resistance is known to precede the occurrence of hyperglycemia [7,8]. The cause of insulin resistance is distinguished by genetic factors and factors obtained. Genetic factors that cause insulin resistance will cause oxidative metabolic disturbances and insulin signaling disturbances [8]. Genetic factors that cause insulin resistance are PPRA¥, PGC1 $\alpha$, HNF4ALPA, and KCNJ11. Skaning genotypes broadly are calpain-10, ENPP1, TCF7L2 and ADIPOR2 [9].

To overcome the problem of hyperglycemia in patients with diabetes is done by diet, physical activity, education, and medicine. To overcome this situation through a diet requires a guide, amount and calorie diet by paying attention to the glycemic index. For that reason, this study conducted a diet selection with certain glycemic index and exercise for patients with type 2 diabetes in Minangkabau ethnicity in the Padang City.

\section{Methods and Materials}

\subsection{Study design and research sample}

This experimental study design was conducted in Padang City from June to December 2017. The number of samples was 55 respondents aged $>40$ years patient given diet and exercise consultation for 3 months and seen blood glucose and insulin patients with type 2 diabetes mellitus.

\subsection{Operational definitions}

The subjects of this study are T2DM patients. Nutritional consultation intervention in the form of diet with diet modification based on the glycemic index according to the type of diet for type 2 diabetes mellitus patients to be carried out at home for 1 month. Exercise intervention for 1 month, based on a) intensity, adjusted for fitness test results or use the formula: $60-90 \%$ (220 age) to get a maximum pulse. Speed is the travel time compared to distance, b) the duration is $30-45$ minutes, c) the frequency is at least 3 times a week. 


\subsection{Research Procedure}

Data were collected from all patients with type 2 diabetes who had blood sugar checked at the Prodia Laboratory Padang City.

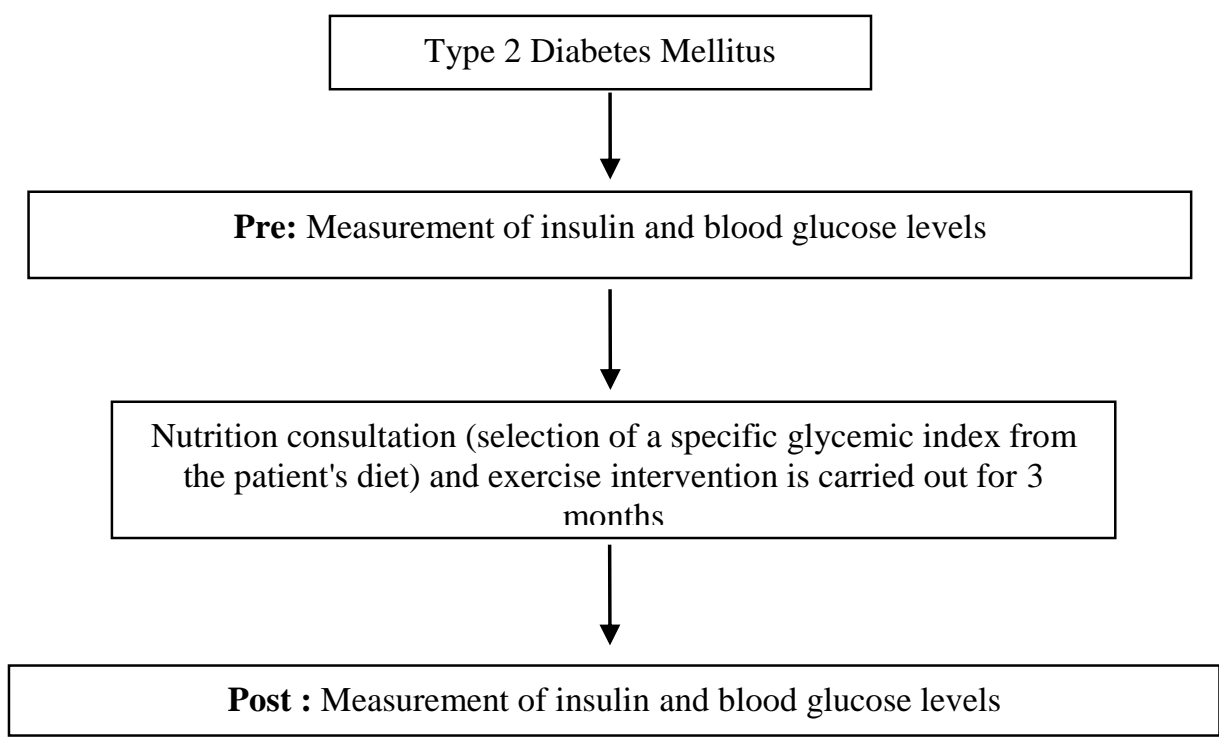

Figure 1. Research procedure

\subsection{Data analysis}

Bivariate analysis of the data in this study was used to find the mean difference of blood glucose and insulin levels between pretest and posttest using paired sample T-test. Data were analyzed by using STATA program. A two-tailed $P$-value of $<0.05$ was considered statistically significant. Data were analyzed using the Stata version 14.2 (Stata Corporation).

\section{Results and Discussions}

Characteristic of respondents (Table 1) 
Table 1. Characteristics of respondents

\begin{tabular}{|c|c|}
\hline Characteristics & $f(\%)$ \\
\hline \multicolumn{2}{|l|}{ Sex } \\
\hline Male & $20(36.4)$ \\
\hline Female & $35(83.6)$ \\
\hline \multicolumn{2}{|l|}{ Age } \\
\hline$<60$ years & $17(30.9)$ \\
\hline $60-64$ years & $8(14.5)$ \\
\hline$\geq 65$ years & $30(54.5)$ \\
\hline \multicolumn{2}{|l|}{ Educational level } \\
\hline Low & $27(49.0)$ \\
\hline High & $28(51.0)$ \\
\hline \multicolumn{2}{|l|}{ Occupation } \\
\hline Civil servant & $9(16.4)$ \\
\hline Entrepreneur & $1(1.8)$ \\
\hline Housewife & $17(30.9)$ \\
\hline Pensionary & $27(39.1)$ \\
\hline Labourer & $1(1.8)$ \\
\hline \multicolumn{2}{|c|}{ Number of family member } \\
\hline $1-2$ & $29(52.7)$ \\
\hline$>2$ & $26(47.3)$ \\
\hline \multicolumn{2}{|c|}{ Body mass index $\left(\mathrm{kg} / \mathrm{m}^{2}\right)$} \\
\hline Normal & $27(49.1)$ \\
\hline Obesity & $28(50.9)$ \\
\hline \multicolumn{2}{|c|}{ Blood glucose levels (mg/dL) } \\
\hline$<125 \mathrm{mg} / \mathrm{dL}$ & $23(41.8)$ \\
\hline$\geq 125 \mathrm{mg} / \mathrm{dL}$ & $25(45.5)$ \\
\hline \multicolumn{2}{|c|}{ Insulin levels (uIU/mL) } \\
\hline$<2 \mathrm{uIU} / \mathrm{mL}$ & $8(14.5)$ \\
\hline $2.3-28.5 \mathrm{uIU} / \mathrm{mL}$ & $29(52.7)$ \\
\hline$>28.5 \mathrm{uIU} / \mathrm{mL}$ & $3(5.5)$ \\
\hline \multicolumn{2}{|c|}{ Family history of diabetes } \\
\hline Yes & $18(32.7)$ \\
\hline No & $37(67.3)$ \\
\hline \multicolumn{2}{|l|}{ Exercise } \\
\hline Routine & $41(74.5)$ \\
\hline Not routine & $14(25.5)$ \\
\hline \multicolumn{2}{|l|}{ Diet discipline } \\
\hline Discipline & $30(54.5)$ \\
\hline Not discipline & $13(23.6)$ \\
\hline
\end{tabular}

Table 2 known that most of the respondents were female $(83.6 \%)$ and less than half of the respondents were male $(36.4 \%)$. More than half of respondents aged $\geq 65$ years $(54.5 \%)$, high educational level (51.0\%), had 1-2 family members (52.7\%). Less than half of respondents were pensionary $(39.1 \%)$ and housewife $(30.9 \%)$. More than half of the respondents were obese $(50.9 \%)$ and less than half of the respondents had a normal body mass index $(49.1 \%)$. Less than half of the respondents had blood glucose levels $\geq 125 \mathrm{mg} / \mathrm{dL}(45.5 \%)$ and $<125 \mathrm{mg} / \mathrm{dL}$ (41.8\%). More than half of respondents had insulin levels $2.3-28.5 \mathrm{uIU} / \mathrm{mL}(52.7 \%)$, had a family history of diabetes $(67.3 \%)$, routine exercise $(74.5 \%)$ and diet discipline $(54.5 \%)$. The 
effect of a diet with certain glycemic index and exercise with blood glucose and insulin levels of type 2 diabetes mellitus patients in Minangkabau ethnicity (Table 2)

Table 2. The effect of a diet with certain glycemic index and exercise with blood glucose and insulin levels of type 2 diabetes mellitus patients in Minangkabau ethnicity

\begin{tabular}{|c|c|c|c|c|}
\hline Variables & $\begin{array}{l}\text { Before } \\
\text { Mean } \pm \text { SD }\end{array}$ & $\begin{array}{l}\text { After } \\
\text { Mean } \pm \text { SD }\end{array}$ & $95 \% \mathrm{CI}$ & p-value \\
\hline $\begin{array}{l}\text { Blood glucose levels } \\
(\mathrm{mg} / \mathrm{dL})\end{array}$ & $142.6 \pm 48.5$ & $133.0 \pm 47.0$ & $0.52-18.53$ & $0.039 *$ \\
\hline Insulin $(\mu \mathrm{LU} / \mathrm{ml})$ & $11.4 \pm 9.9$ & $8.4 \pm 9.1$ & $-1.28-7.30$ & 0.163 \\
\hline
\end{tabular}

$* \mathrm{P}<0.05$, significance

Table 2 known that blood glucose levels before intervention were $142.6 \pm 48.5 \mathrm{mg} / \mathrm{dL}$, while after intervention $133.0 \pm 47.0 \mathrm{mg} / \mathrm{dL}$. Statistical test results obtained $\mathrm{p}=0.039(\mathrm{p}<0.05)$, there is an effect of a diet with certain glycemic index and exercise with blood glucose levels of type 2 diabetes mellitus patients in Minangkabau ethnicity. Insulin levels before intervention were $11.4 \pm 9.9 \mu \mathrm{LU} / \mathrm{ml}$, while after intervention $8.4 \pm 9.1 \mu \mathrm{LU} / \mathrm{ml}$. Statistical test results obtained $\mathrm{p}=0.163(\mathrm{p}>0.05)$ there is no effect of a diet with certain glycemic index and exercise with insulin levels of type 2 diabetes mellitus patients in Minangkabau ethnicity (Figure 1).
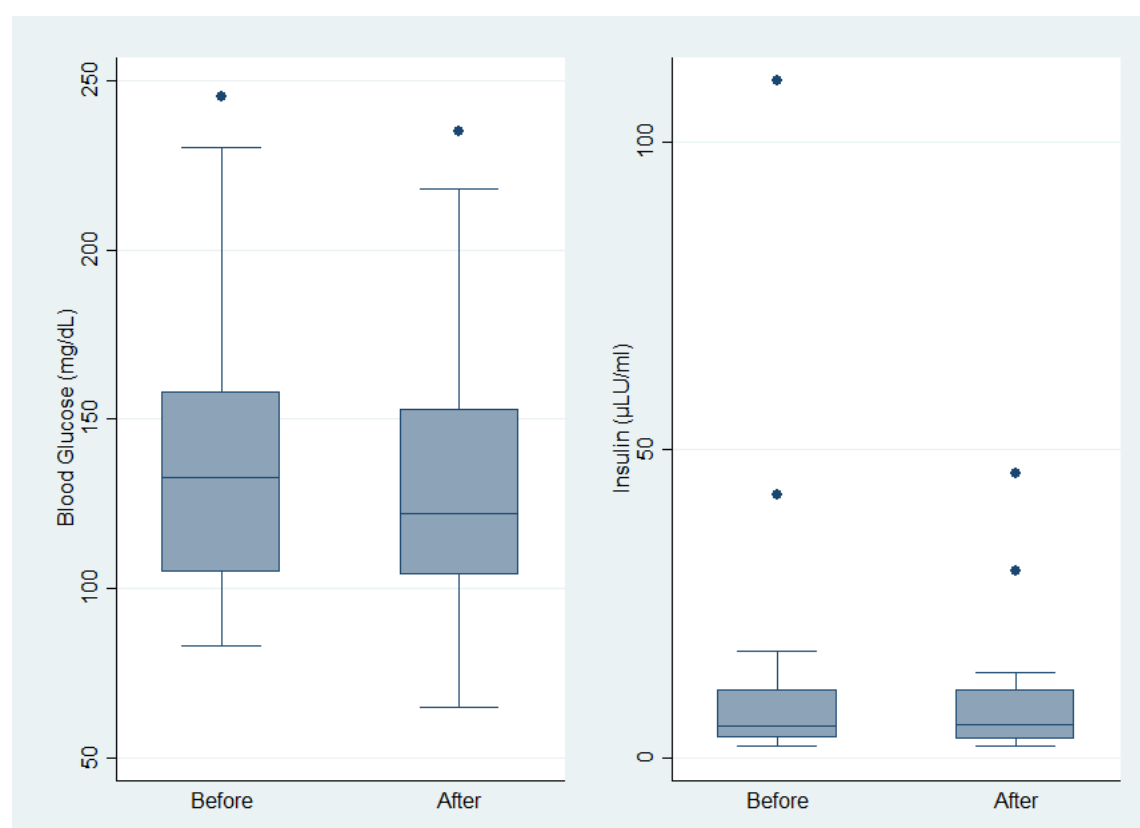

Figure 1. The effect of a diet with certain glycemic index and exercise with blood glucose and insulin levels of type 2 diabetes mellitus patients in Minangkabau ethnicity 


\section{Discussion}

The results showed blood glucose levels before intervention were $142.6 \pm 48.5 \mathrm{mg} / \mathrm{dL}$, while after intervention $133.0 \pm 47.0 \mathrm{mg} / \mathrm{dL}$. Statistical test results obtained $\mathrm{p}=0.039(\mathrm{p}<0.05)$, there is an effect of a diet with certain glycemic index and exercise with blood glucose levels of type 2 diabetes mellitus patients in Minangkabau ethnicity. Insulin levels before intervention were $11.4 \pm 9.9 \mu \mathrm{LU} / \mathrm{ml}$, while after intervention $8.4 \pm 9.1 \mu \mathrm{LU} / \mathrm{ml}$. Statistical test results obtained $p=0.163(p>0.05)$ there is no effect of a diet with certain glycemic index and exercise with insulin levels of type 2 diabetes mellitus patients in Minangkabau ethnicity.

Each person needs individualized treatment. Type-2 diabetes always requires insulin, diet, and exercise. People with type-2 diabetes require insulin or oral hypoglycemic agents (medication that helps lower blood sugar). The beneficial effect of the dietary pattern on diabetes mellitus and glucose metabolism in general and traditional food pattern was associated with a significant reduction in the risk of developing type-2 diabetes [10],[11].

The dietary pattern emphasizes consumption of fat primarily from foods high in unsaturated fatty acids and encourages daily consumption of fruits, vegetables, low-fat dairy products, and whole grains, low consumption of fish, poultry, tree nuts, legumes, very less consumption of red meat [10]-[12]. The composition of the diet is one of the best known dietary patterns for its beneficial effects on human health that may act beneficially against the development of type-2 diabetes, including reduced oxidative stress and insulin resistance. High consumption of vegetables, fruits, legumes, nuts, fish, cereals and oil leads to a high ratio of monounsaturated fatty acids to saturated fatty acids, a low intake of trans fatty acids, and high ingestion of dietary fiber, antioxidants, polyphenols. The diets are characterized by a low degree of energy density overall; such diet prevents weight gain and exerts a protective effect on the development of type-2 diabetes, a condition that is partially mediated through weight maintenance. Greater adherence to the diet in combination with light physical activity was associated with lower odds of having diabetes after adjustment for various factors [13]-[17].

This study found there is no effect of a diet with certain glycemic index and exercise with insulin levels of type 2 diabetes mellitus patients in Minangkabau ethnicity. These things happened several important conclusions: a) In patients T2DM, it appears that the certain glycemic index did not substantially influence insulin sensitivity, because there are genetic factors especially family history of diabetes mellitus, in our study found $32.7 \%$, b) body weight not reduced significantly after 12 weeks of intervention, which may have did not contribute to reducing insulin sensitivity.

\section{Conclusion}

In conclusion, our study found there is an effect of a diet with certain glycemic index and exercise with blood glucose levels of type 2 diabetes mellitus patients in Minangkabau ethnicity, but insulin levels this effect was not significant. Several factors may contribute such as family history of diabetes mellitus and body weight not reduced significantly after 12 weeks of intervention. This study suggests, need to measure the adherence of patients to diet and exercise therapy to achieve normal fasting blood glucose levels and normal body mass index.

Conflict of interest. The authors declare no conflict of interest. 
Acknowledgements. The authors would like to thank Ricvan Dana Nindrea, MPH for data analysis.

\section{References}

[1]. ild S, Roglic G, Green A, Sicree R, King H. Global prevalence of diabetes: Estimates for the year 2000 and projections for 2030. Diabetes Care. 2004;27:1047-53

[2]. Ministry of Health Republic of Indonesia. Basic health research reports. Ministry of Health Republic of Indonesia, Jakarta, 2007.

[3]. Levitan EB, Song Y, Ford ES, Liu S. Is nondiabetic hyperglycemia a risk factor for cardiovascular disease? A meta-analysis of prospective studies. Arch Intern Med. 2004 ;164(19):2147-55

[4]. Nakagami T, Qiao Q, Tuomilehto J, Balkau B, Tajima N, Hu G, et al. Screen-detected diabetes, hypertension and hypercholesterolemia as predictors of cardiovascular mortality in five populations of Asian origin: the DECODA study. Eur J Cardiovasc Prev Rehabil. 2006;13(4):555-61.

[5]. Kaneto H, Matsuoka TA, Nakatani Y, Kawamori D, Miyatsuka T, Matsuhisa M, Yamasaki Y. Oxidative stress, ER stress, and the JNK pathway in type 2 diabetes. J Mol Med (Berl). 2005;83(6):429-39.

[6]. Hirosumi J, Tuncman G, Chang L, Gorgun CZ, Uysal KT, Maeda K, et al. A central role for JNK in obesity and insulin resistance. Nature. 2002;420(6913):333-6

[7]. Furukawa S, Fujita T, Shimabukuro M, Iwaki M, Yamada Y, Nakajima Y, et al. Increased oxidative stress in obesity and its impact on metabolic syndrome. $J$ Clin Invest. 2004;114(12):1752-61.

[8]. Schenk S, Saberi M, Olefsky JM. Insulin sensitivity : modulation by nutriets and inflammation. J Clin Invest. 2008;118(9):2992-3002.

[9]. Barry JG, Muller-Wieland D. Type 2 Diabetes : Prinsip and practice, Informa Healthcare USA, Inc, New York, 2008.

[10].American Diabetes Association. Standards of medical care in diabetes-2010. Diabetes Care. 2010;33(1):S11-61.

[11]. American Diabetes Association: Evidence-based nutrition principles and recommendations for the treatment and prevention of diabetes and related complications (Position Statement) Diabetes Care. 2003;26(1):S51-61.

[12]. Barnard ND, Scialli AR, Turner-McGrievy G, Lanou AJ, Glass J. The effects of a lowfat, plantbased dietary intervention on body weight, metabolism, and insulin sensitivity. Am J Med. 2005;118:991-7.

[13].American Diabetes Association. Standards of Medical Care in Diabetes-2008. Diabetes Care. 2008;31:S12-S54.

[14].Barnard ND, Scialli AR, Turner-McGrievy GM, Lanou AJ. Acceptability of a low-fat vegan diet compares favorably to a step II diet in a randomized, controlled trial. J Cardiopulm Rehabil. 2004;24:229-35.

[15].Barnard RJ, Jung T, Inkeles SB. Diet and exercise in the treatment of NIDDM: The need for early emphasis. Diabetes Care. 1994;17:1-4.

[16]. Wieland H, Seidel D. A simple specific method for precipitation of low density lipoproteins. J Lipid Res. 1983;24:904-9.

[17]. Yang W, Lu J, Weng J, Jia W, Ji L, Xiao J, et al. Prevalence of diabetes among men and women in China. N Engl J Med. 2010;362:1090-101. 